\title{
Impact of COVID- 19 on the Psychological Health of Dental Professionals: A Systematic Review
}

\author{
Dilan A Gohil ${ }^{1}$, Richard D Nair ${ }^{2}$, Masoud Mohammadnezhad ${ }^{2} \&$ K. Venkata Raman Reddy ${ }^{3}$ \\ ${ }^{1}$ Department of Oral Health, Colonial War Memorial Hospital, Suva, Fiji \\ ${ }^{2}$ School of Public Health and Primary Care, Fiji National University, Suva, Fiji \\ ${ }^{3}$ Department of Oral Health, Rakiraki District Hospital, Rakiraki, Fiji \\ Correspondence: Masoud Mohammadnezhad, Associate Professor in Public Health (Health Promotions) School \\ of Public Health and Primary Care, Fiji National University, Suva, Fiji.
}

Received: April 5, 2021 Accepted: May 6, 2021 Online Published: May 15, 2021

doi:10.5539/gjhs.v13n7p1 URL: https://doi.org/10.5539/gjhs.v13n7p1

\begin{abstract}
Background: An outbreak of novel coronavirus disease (COVID-19), has influenced every aspect of life. Healthcare workers, especially dentists, are at a high risk of getting infected due to close contact with patients Aim: to identify factors that can affect the psychological health of dental professionals during the COVID - 19 pandemic.

Method: This systematic review was conducted for the full-text English articles focusing in the field of dentistry, specifically looking at the impact of COVID - 19 on the psychological health of dental professionals, from January $1^{\text {st }} 2020$ to April $1^{\text {st }} 2021$.

Results: A total of 677 papers were retrieved, reduced to 136 following removal of duplicates. The abstracts were screened using the eligibility criteria, and 52 were found to match the criteria. After screening the full-text articles, 32 were excluded, resulting in a total of 20 studies. The significant findings and conclusions from these studies were extracted and grouped under themes.

Conclusion: The 3 major factors responsible for affecting the psychological health of dental professionals during the COVID - 19 pandemic include: fear of contagion, subjective overload, and perceived job insecurity and loss of income. There is a need for countries to enact measures that ensure positive mental wellbeing of dental professionals, so that they do not take any adverse action or decisions. Furthermore, should another pandemic or viral outbreak occur in the future, policies and strategies designed and implemented, will ensure dental professionals continue to deliver service without significant psychological distress.
\end{abstract}

Keywords: COVID - 19, Dental Professionals, Dentistry, Psychological Health, Systematic Review

\section{Introduction}

In January 2020, the Chinese Centre for Disease Control and Prevention (CCDCP) announced that a coronavirus, Severe Acute Respiratory Syndrome (SARS)-CoV-2, was responsible for the novel pneumonia cases recorded in Wuhan, Hubei Province, later named Coronavirus virus disease of 2019 (COVID-19) by the World Health Organization (WHO) (Zheng, 2020). COVID-19 had spread worldwide in a matter of months, which compelled the WHO to declare it as a controllable pandemic on $11^{\text {th }}$ March, 2020. ("Coronavirus Disease (COVID-19) events as they happen", 2021). Although COVID - 19 has a low mortality rate, it has a high potential for spreading (Chen, 2020). This characteristic of the virus has had an effect on every aspect of life (Gralinski \& Menachery, 2020). Many countries have shut down or reduced non-essential facilities, sports activities, social gatherings, and even airports to contain the spread of infection due to the rapid and debilitating nature of COVID - 19 outbreaks. Healthcare services, on the other hand, are a necessity in any community and are seldom closed (Ahmed et al., 2020). Furthermore, healthcare professionals are deemed as "frontline workers" and are expected to step up and deliver services even in times of pandemic or emergency (Ather, Patel, Ruparel, Diogenes \& Hargreaves, 2020). Medical personnel all over the world are under constant and high-level stress as a result of the raging COVID - 19 contagions, which includes increased risk of infection, fatigue, anger, social exclusion, and being separated from their families (Kang et al., 2020). Such traumatic events during the COVID - 19 pandemic, can increase the risk of medical personnel in developing stress and anxiety disorders, such as Post-Traumatic Stress Disorder (PTSD) 
(Huang, Han, Luo, Ren, \& Zhou, 2020). Subsequently, these mental health issues could have a negative impact on the medical personnel's decision-making capacity, resulting in less-than-optimal care for their patients as well as a decline in their psychological well-being (Kang et al., 2020). For several years, studies have suggested that, dentistry generates more stress than any other medical profession, primarily because of the nature and working conditions of the dental surgery (Bourassa \& Baylard, 1994; Cooper, Watts, \& Kelly, 1987; Moore \& Brødsgaard, 2001). Statistics on dentistry and; alcoholism, drug abuse, divorce, cardiovascular disease, and elevated rates of suicide, suggests that the typical life of a General Dental Practitioner (GDP) is a stressful one (Cooper \& Marshall, 1980; Kent 1987; Stack, 2001). In a study conducted in the United Kingdom (UK), by Myers and Myers (2004), on self-reported questionnaires of $2441 \mathrm{GDP}$, it was found that over $60 \%$ of the dentists described being; nervous, tense, tired, and depressed due to work pressure. With COVID - 19 cases surging worldwide, it is natural for dentists to feel even more stressed and fearful than before. This is because, COVID-19 has the potential to cause serious Acute Respiratory Tract Infection (ARTI) in infected humans, and it is spread from person to person through hands, saliva, nasal droplets, and surface contacts. (Chen, Liu, \& Guo, 2020; Peng et al., 2020). Dentists are particularly affected by the risk of being infected by COVID - 19, as they not only work in close contact with patients, but are also exposed to aerosols and droplets splashing out of the patient's oral cavity (Ather et al., 2020; Meng, Hua, \& Bian, 2020). Moreover, in the dental operatory, the possible routes for the spread of COVID - 19 include: direct contact with the body fluids of an infected patient, the touching of environmental surfaces and instruments contaminated with the body fluids of a COVID- 19 positive person (Meng et al., 2020), and potential contact with infectious particles that have become airborne due to the aerosol generating procedure (Ren, Rasubala, Malmstrom, \& Eliav, 2020). Till date, there is no declaration that COVID - 19 is transmitted through air, but based on the trend in the increase in the number of infections, and the understanding of the basic science of viral disease, we should contemplate the potential airborne transmission of COVID-19 (Morawska \& Cao, 2020; Morawska \& Milton, 2020).Thus, it could be said that dentists are on the list of occupations with a high level of risk to COVID - 19, and are likely to experience extreme anxiety as a result of the current pandemic situation $(\mathrm{Ng}$ et al., 2020). Mild anxiety is normal and encourages protective and preventative action (Fazel, Hoagwood, Stephan, \& Ford, 2014). However, in the given scenario, people including dentists, who suffer from chronic anxiety are more likely to panic and make mistakes, which can lead to unreasonable decisions and behavior (Ahmed et al., 2020). Therefore, the aim of this systematic review is to identify the factors that can affect the psychological health of dental professionals during the COVID - 19 pandemic.

\section{Method}

\subsection{Search Strategy and Information Sources}

This systematic review was performed in accordance with the Preferred Reporting Items for Systematic Reviews and Meta-Analyses (PRISMA) (Hutton et al., 2015). Research was done to find the answer to the question "factors that can affect the psychological health of dental professionals during COVID - 19". The research focused question was identified with the aid of the PICO format: (P) is for the Participants, (I) for the Intervention, (C) for the Comparison and (O) for the Outcome (Schardt, Adams, Owens, Keitz \& Fontelo, 2007). (P) were the studies that focused on dental professionals during COVID - 19, (I) were situations during COVID - 19, that caused stress and anxiety amongst dental professionals, (C) were situations during COVID - 19, that did not cause stress and anxiety amongst dental professionals $(\mathrm{O})$ were factors that can affect the psychological health of dental professionals during COVID - 19. An electronic search was conducted in Medline/Pubmed, Embase and Proquest databases. To achieve all relevant studies, gray literature search was also conducted in Google Scholar and OpenGrey. This literature review focused on several aspects related to the impact of COVID - 19 on the psychological health of dental professionals. The keywords used included: (COVID -19 OR coronaviruses) AND (psychological OR mental OR stress OR anxiety) AND (dentist* OR "Paedodontist OR "pediatric dentist" OR orthodontist OR periodontist OR endodontist OR "oral pathologist" OR "oral surgeon"; prosthodontist) AND ("dental services" OR "oral health") AND (factors OR determinants). The focus of the search was studies published between January $1^{\text {st }} 2020$ to April $1^{\text {st }} 2021$ in English language.

\subsection{Inclusion Criteria}

Inclusion criteria were as follows:

- $\quad$ Studies from January $1^{\text {st }} 2020$ to April $1^{\text {st }} 2021$.

- Studies looking at the impact of COVID - 19 on the psychological health of dental professionals in work setting. 


\subsection{Exclusion Criteria}

Exclusion criteria were as follows:

- Unpublished articles.

- Case reports, short communications, and letters to the editor.

- Studies looking at the impact of COVID - 19 on the psychological health of dental students in university setting.

\subsection{Study Selection and Quality Assessment}

All the study titles were entered to Endnote and duplicated studies were excluded when the titles of all the studies were scanned by two independent researchers. The abstracts of the remaining studies were reviewed, and those that did not meet the inclusion criteria were excluded. Finally, the full text of the manuscripts that met the study inclusion criteria were printed for future review.

\subsection{Data Extraction}

For every study included in this research, the study characteristics as well as information regarding the exposure, outcome, and results were extracted in Microsoft Excel. 1. The study information, include: geographic location, time frame, research design, sample size, percentage of respondents among eligible participants, and number of institutions/ countries involved. 2. Characteristics of participants include: the age category, gender, specialties, career level. 3. Outcomes include: depressive/anxiety symptoms measure, emotional response (Table 1). One reviewer completed data extraction for each study and a second reviewer checked the extracted data. A third reviewer then checked all extracted resource.

\section{Results}

A total of 677 papers were retrieved, reduced to 136 following removal of duplicates. The abstracts were screened using the eligibility criteria, and 52 were found to match the criteria. After screening the full-text articles, 32 were excluded, resulting in a total of 20 studies. These twenty studies were selected in the review to formulate the themes made in this study, which will be further elaborated. (Figure 1).

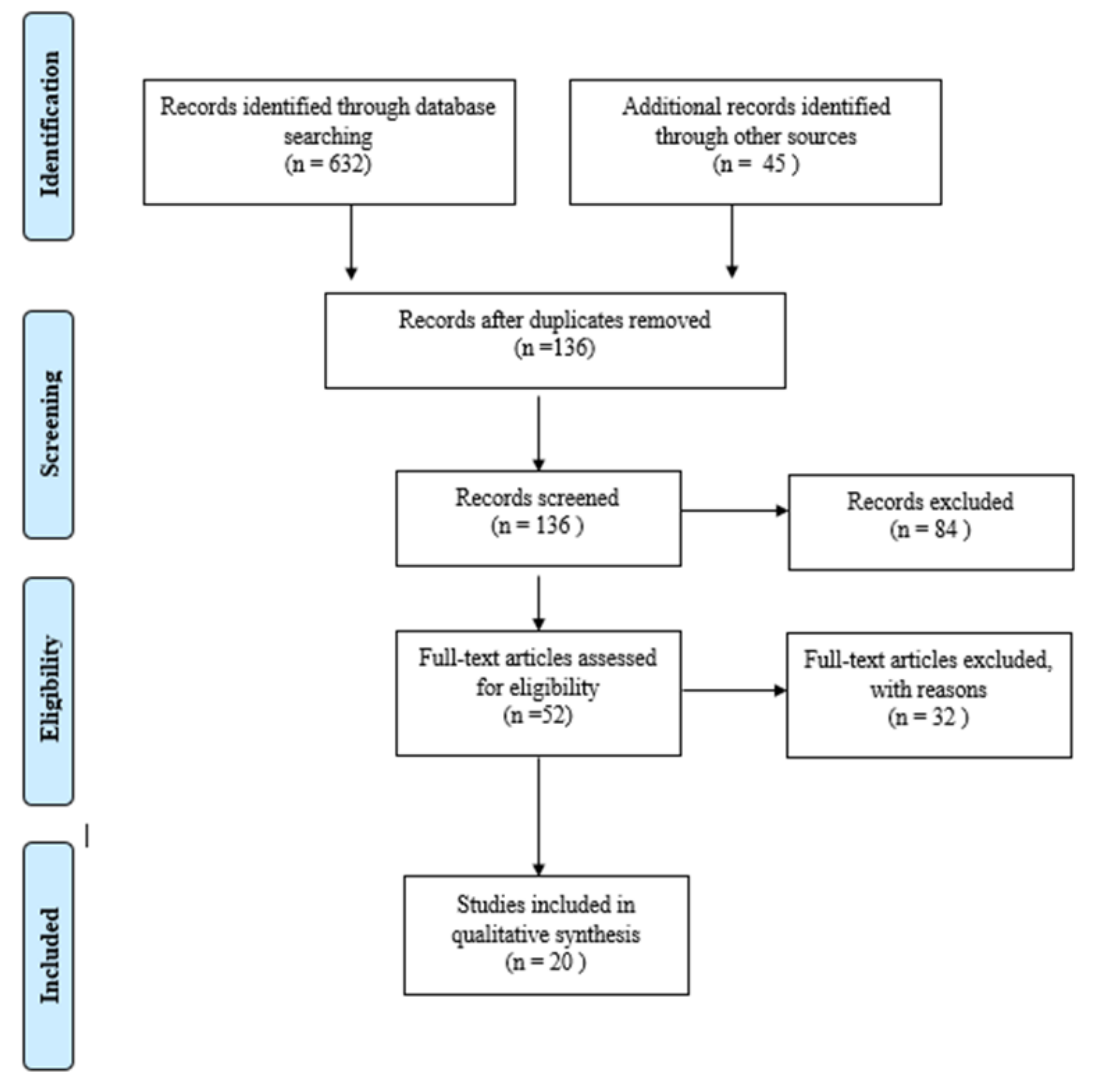

Figure 1. Flow chart of study selection process 
Table 1. Selected characteristics of the twenty included studies

\begin{tabular}{|c|c|c|c|c|c|c|}
\hline Authors & Time Frame & Country & Specialties & Study Design & Sample Size & Results \\
\hline $\begin{array}{l}\text { Ahmed et al. } \\
(2020)\end{array}$ & $\begin{array}{l}10^{\text {th }}-17^{\text {th }} \text { March } \\
2020\end{array}$ & 30 countries & Dentists & $\begin{array}{l}\text { Cross } \\
\text { Sectional }\end{array}$ & 650 & $\begin{array}{l}\text { r of Contagion } \\
\text { - } \quad 87 \% \text { were concerned about contracting COVID- } 19 \text { from } \\
\text { a patient or coworker. } \\
\text { - During the treatment of a coughing or a patient suspected } \\
\text { of being infected with COVID-19, } 90 \% \text { were nervous. } \\
\text { - While speaking with patients in close proximity, } 72 \% \text { felt } \\
\text { anxious. } \\
\text { - } 92 \% \text { were concerned about spreading the infection from } \\
\text { their dentist's office to their relatives. } \\
86 \% \text { expressed fear after learning of COVID-19-related } \\
\text { - deaths; } \\
66 \% \text { expressed a desire to close their dental practices } \\
\text { until the number of COVID-19 cases began to decrease. }\end{array}$ \\
\hline $\begin{array}{l}\text { Consolo et al. } \\
(2020)\end{array}$ & $\begin{array}{l}2^{\text {nd }}-21^{\text {st }} \text { April } \\
2020\end{array}$ & Italy & Dentists & $\begin{array}{l}\text { Cross } \\
\text { Sectional }\end{array}$ & 356 & $\begin{array}{l}\text { r of Contagion } \\
\text { - } 85 \% \text { were anxious about contracting COVID - } 19 \text { during } \\
\text { their clinical activity } \\
\text { - } 4.2 \% \text { reported to experiencing fear very intensely, and } \\
6.2 \% \text { responded to experiencing anxiety intensely. } \\
\text { - } 12.6 \% \text { felt intensely sad, and anger was intensely } \\
\text { experienced by } 9.3 \% \text {. }\end{array}$ \\
\hline $\begin{array}{l}\text { Duruk et al. } \\
(2020)\end{array}$ & $\begin{array}{l}16^{\text {th }}-20^{\text {th }} \text { March } \\
2020\end{array}$ & Turkey & $\begin{array}{l}\text { Dentists and } \\
\text { Dental specialists }\end{array}$ & $\begin{array}{l}\text { Cross } \\
\text { Sectional }\end{array}$ & 1958 & $\begin{array}{l}\text { r of Contagion } \\
\text { - } 90 \% \text { were worried about getting infected with COVID - } \\
19 . \\
\text { - } 95 \% \text { were concerned about carrying the virus to their } \\
\text { families. } \\
\text { - As the level of awareness about COVID - } 19 \text { grew, so did } \\
\text { psychological distress. }\end{array}$ \\
\hline $\begin{array}{l}\text { De Stefani et al. } \\
(2020)\end{array}$ & $\begin{array}{l}11^{\text {th }}-18^{\text {th }} \text { April } \\
2020\end{array}$ & Italy & Dentists & $\begin{array}{l}\text { Cross } \\
\text { Sectional }\end{array}$ & 1500 & $\begin{array}{l}\text { ceived job insecurity and loss of income } \\
\text { - Significant apprehension for the economic situation was } \\
\text { felt by dentists. Apprehension could be attributed to the } \\
\text { high prevalence of dentists in private practice, who saw } \\
\text { their income loss critically. }\end{array}$ \\
\hline
\end{tabular}




\section{Fear of Contagion}

- Participants knowing more than one people who had died due to COVID-19 had higher levels of depressive symptoms

Subjective Overload

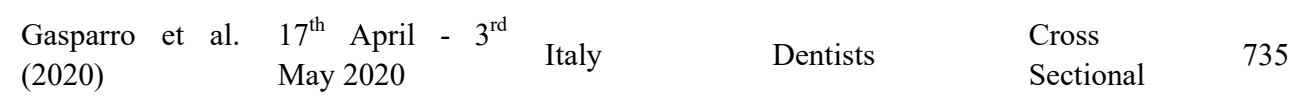

- Female dentists seemed to have a greater fear of than males.

- Young dentists with fewer years of work experience were associated with higher levels of depressive symptoms.

Perceived Job insecurity and loss of income

- Dentists with low fear of COVID -19 had weaker perceived job insecurity and depressive symptoms, compared to their colleagues who displayed higher fear to COVID - 19

\begin{tabular}{|c|c|c|c|c|c|}
\hline $\begin{array}{l}\text { Mijiritsky et al. } \\
(2020)\end{array}$ & $\begin{array}{l}30^{\text {th }} \text { March }-12^{\text {th }} \\
\text { April } 2020\end{array}$ & $\begin{array}{l}\text { China, India, } \\
\text { Israel, Italy, } \\
\text { and the UK }\end{array}$ & Dentists & $\begin{array}{l}\text { Cross } \\
\text { Sectional }\end{array}$ & 1302 \\
\hline
\end{tabular}

Subjective Overload

- Italian dentists showing more psychological distress in comparison to dentists from China, India, UK, and Israel.

\section{Subjective Overload}

- High subjective overload and a low self-efficacy score were found to be linked to increased psychological distress.

- Dental workers with a high self-efficacy score showed less psychological distress.

- Dental workers with medical condition, had higher levels of psychological distress.

- Dental staff with background illnesses exhibited elevated psychological distress.

- Dental staff in a committed relationship reported of lower psychological distress.

\section{Subjective Overload}

\begin{tabular}{|c|c|c|c|c|}
\hline $\begin{array}{l}\text { Tysiąc-Miśta and } \\
\text { Dziedzic (2020) }\end{array}$ & $\begin{array}{l}6^{\text {th }}-16^{\text {th }} \text { April } \\
2020\end{array}$ & Poland & Dentists & $\begin{array}{l}\text { Cross } \\
\text { sectional }\end{array}$ \\
\hline
\end{tabular}

- Female dentists were more likely to suspend their clinical practice due to self - reported feeling of anxiety.

- The highest level was anxiety was observed in the group of non - working women, and the lowest, in the group of 


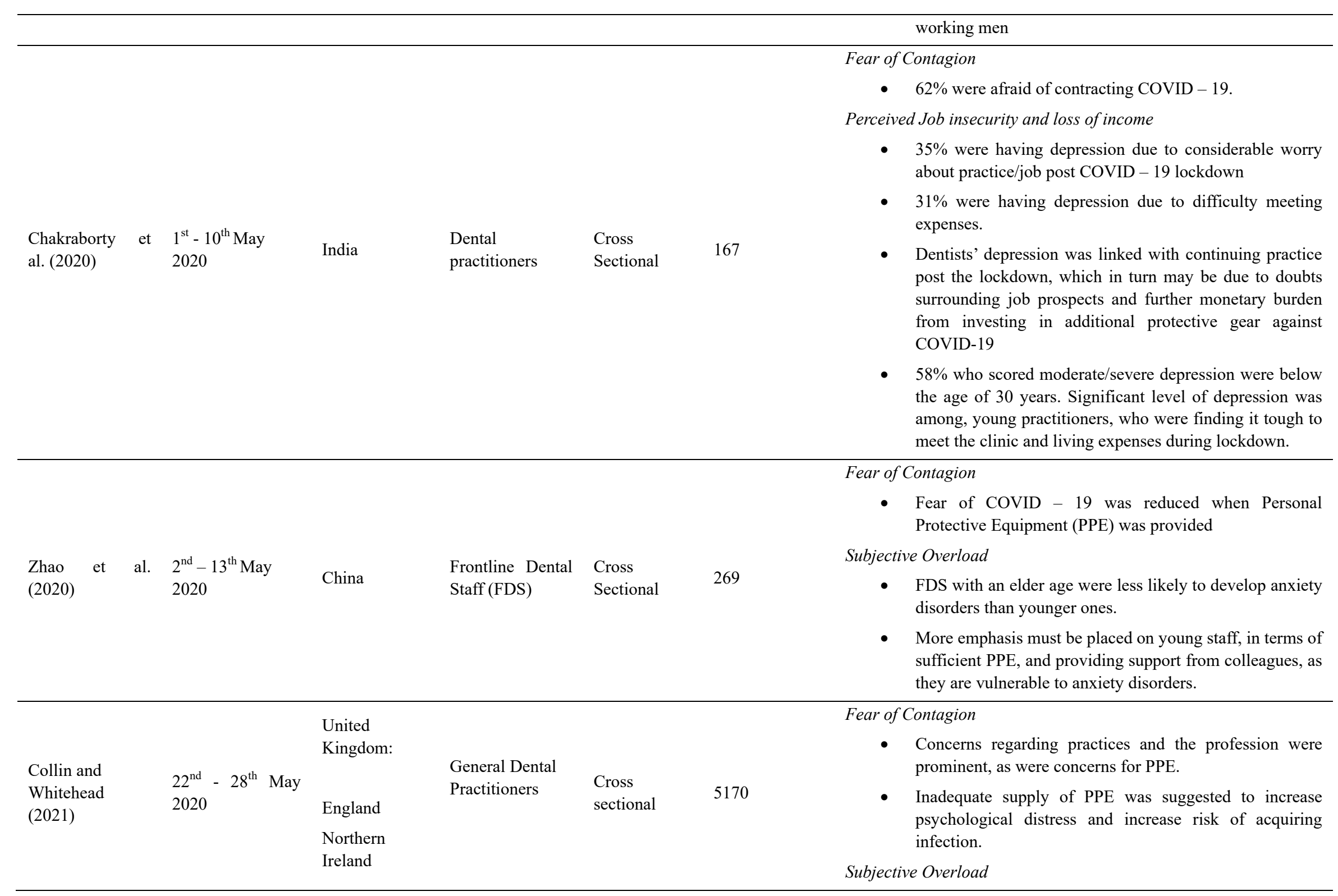


Scotland

Wales
- Psychological distress was also attributed to feelings of betrayal compounded by lost trust in leaders of the profession and the lack of communication during the pandemic.

Perceived job insecurity and loss of income

- $77 \%$ stated that the pandemic had affected them financially.

- $\quad$ For dentists working in general practice, practice owners reported significantly greater psychological distress $(64.8 \%)$ compared to associates $(55.3 \%)$. This is because, practice owners have the financial liability of trying to maintain their business

\begin{tabular}{|c|c|c|c|c|c|c|}
\hline & & & & & & $\begin{array}{l}\text { Fear of Contagion } \\
\text { - Almost everyone felt the necessity to wear hazmat suits } \\
\text { when treating patients particularly the aerosol-generating } \\
\text { procedures }(96.6 \%)\end{array}$ \\
\hline $\begin{array}{l}\text { Shetty et al. } \\
(2020)\end{array}$ & $\begin{array}{l}\text { March - May } \\
2020\end{array}$ & India & $\begin{array}{l}\text { Dental } \\
\text { Practitioners }\end{array}$ & $\begin{array}{l}\text { Cross } \\
\text { Sectional }\end{array}$ & 405 & $\begin{array}{l}\text { Subjective Overload } \\
\text { - Women reported to have higher anxiety score than males. } \\
\text { - Age of the dental clinicians was found to be a positive } \\
\text { factor and directly proportional to high anxiety score. } \\
\text { - Majority of the respondents above } 35 \text { years of age were } \\
\text { noted to be relatively more anxious in all aspects }\end{array}$ \\
\hline $\begin{array}{l}\text { Sarapultseva et } \\
\text { al. }(2021)\end{array}$ & $\begin{array}{l}1^{\text {st }}-20^{\text {th }} \\
\text { September } 2020\end{array}$ & Russia & $\begin{array}{l}\text { Dentists, } \\
\text { Dental assistants, } \\
\text { and } \\
\text { other HCW }\end{array}$ & $\begin{array}{l}\text { Cross } \\
\text { Sectional }\end{array}$ & 128 & $\begin{array}{l}\text { Subjective Overload } \\
\text { - Health Care Workers (HCW) aged } 51-64 \text { showed higher } \\
\text { depression scores, in comparison to age group } 18-35 \text {, and } \\
36-50 .\end{array}$ \\
\hline $\begin{array}{l}\text { Mishra et al. } \\
(2020)\end{array}$ & $\begin{array}{l}\text { 1) } 20^{\text {th }}-25^{\text {th }} \\
\text { March } 2020 \\
\text { (Phase } 1 \text { ) }\end{array}$ & India & Dentists & $\begin{array}{l}\text { Cross } \\
\text { sectional }\end{array}$ & 1253 & $\begin{array}{l}\text { Fear of Contagion } \\
\text { - Concern about COVID-19 contagion and getting infected } \\
\text { with it, was one of the most frequent sources of stress } \\
\text { amongst dentists. } \\
\text { Perceived job insecurity and loss of income } \\
\text { - Since the lockdown was enforced, dentists seemed to be } \\
\text { facing financial hardships, as majority of them were }\end{array}$ \\
\hline
\end{tabular}


2) $25^{\text {th }}-30^{\text {th }}$ April

2020 (Phase 2) concerned about losing their job or loss of earning in the practice, or practice needing large investments in infection control procedures.

\section{Subjective Overload}

- Female dentists more afraid of the current crisis, compared to males.

$\begin{array}{lllllll}\begin{array}{l}\text { Majeed } \\ (2021)\end{array} & \text { et } & \text { al. } & \text { May 2020 } & \text { Pakistan } & \text { Dentists } & \begin{array}{l}\text { Cross } \\ \text { Sectional }\end{array}\end{array}$

Young dentists below the age of 30 expressed higher levels of anxiety than dentists aged 31 to 50 years. However, dentists above the age of 50 had highest level of anxiety among all age groups.

Fear of Contagion

- $28.4 \%$ were "extremely stressed" at the prospect of passing the coronavirus to their families.

$\begin{array}{llllll}\text { Sarialioglu et al. } & 5^{\text {th }}-12^{\text {th }} & \text { May } & \text { Turkey } & \text { Dentists } & \text { Cross } \\ (2021) & 2020 & & & \text { Sectional } & 1095\end{array}$

\section{Subjective Overload}

- Stress was reported to be higher in females than males

- Dentists with more than 20 years of professional experience had lower stress levels than less experienced colleagues.

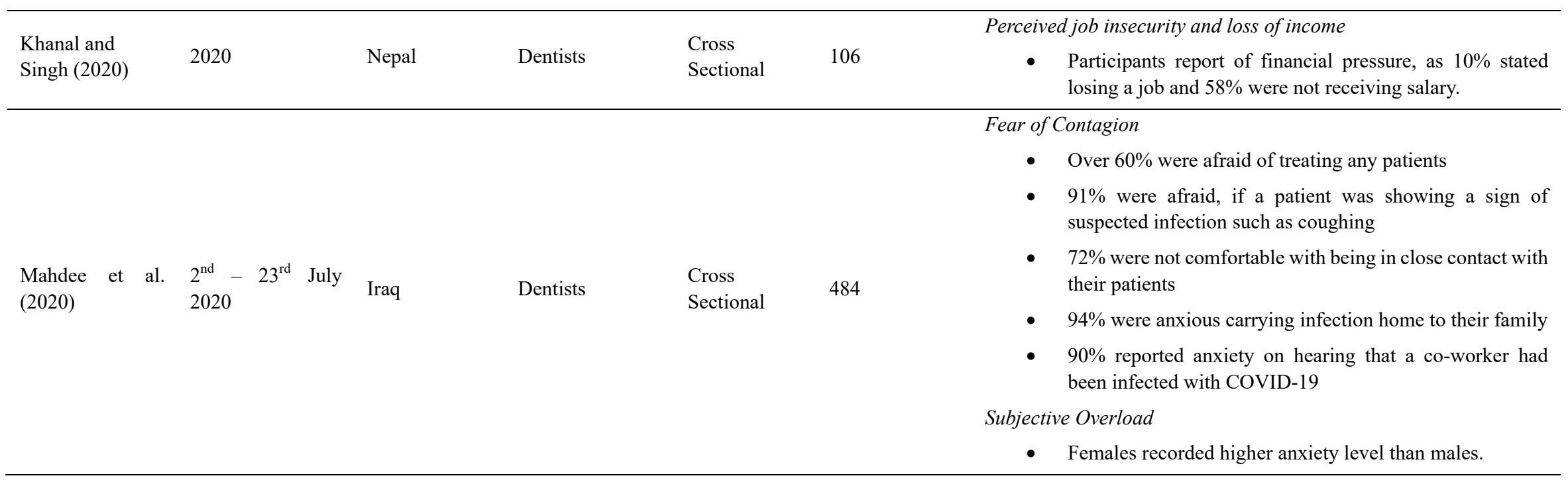


- Younger dentists experienced greater anxiety than older dentists.

Perceived job insecurity and loss of income

- More than $75 \%$ reported that their income had dropped by $25-50 \%$.

- Females exhibited significantly higher scores for anxiety and stress than their male counterparts

- Being single, married, or in marriage - like relationship and having kids, was associated with lower anxiety in the

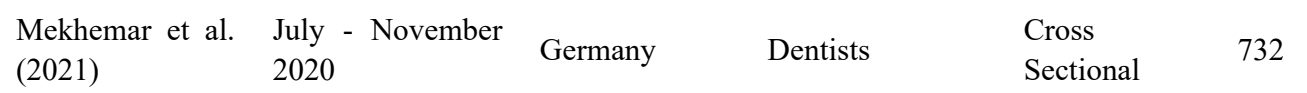
participants compared to being divorced, widowed, separated or having no kids.

- The oldest age group (over 60 years old) of the study showed lower depression and anxiety scores than the youngest participants in age group (18-49 years) and (5059 years)

\section{Fear of Contagion}

- Most were afraid of getting infected with COVID-19 from a patient or a co-worker and were anxious while providing treatment to a suspected patient

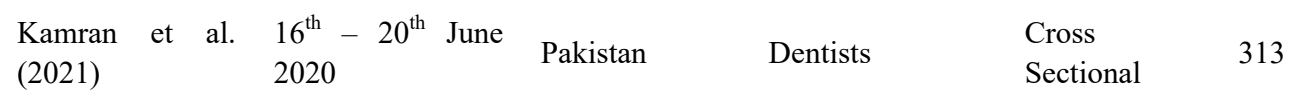

- $\quad 92 \%$ had fear that they would carry the infection back to their family.

- $80.9 \%$ wanted to close their dental practice until the number of COVID-19 cases start declining 


\subsection{Description of Studies}

Twenty cross - sectional studies, involving 18222 dental professionals from 33 countries were included. Three (15\%) from Italy, one (5\%) from Poland, two (10\%) from Turkey, one (5\%) from China, one (5\%) from Russia, one (5\%) from Israel, three (15\%) from India, one (5\%) from Nepal, two (10\%) from Pakistan, one (5\%) from Iraq, one (5\%) from Germany, and three studies (15\%) involved more than 1 country. All studies utilized self-reported information on anxiety/depression/fear/uncertainty in dental practice due to COVID - 19 .

Three themes were established from the analysis: fear of contagion, subjective overload, and perceived job insecurity and loss of income, which will be discussed further.

\subsection{Theme 1: Fear of Contagion}

Fear of contagion/COVID - 19 has been investigated in 12 studies. It was established by Ahmed et al. (2020), Consolo, Bellini, Bencivenni, Iani and Checchi (2020), Chakraborty, Subbiah and Damade (2020), Duruk, Gümüşboğa and Çolak (2020), Mishra et al. (2020), Kamran, Saba and Azam (2021), Mahdee, Gul, Abdulkareem and Qasim (2020), Sarialioglu Gungor, Donmez and Uslu (2021), that many dentists are afraid of being infected by their patients or coworkers and spreading the infection from the dental office to their families, and that the majority of dentists are afraid of treating any patient who exhibits suspicious symptoms. It was highlighted by Duruk et al. (2020), that psychological distress increased as the level of knowledge about COVID - 19 increased. In addition, Gasparro et al. (2020) concluded that, dentists knowing more than one person who had died due to COVID-19 reported of higher levels of depressive symptoms. It was noted by Collin and Whitehead (2021), Shetty et al. (2020), Zhao, Cao, Sun, Zhang and Liu (2020), that the fear of COVID - 19 was reduced when proper Personal Protective Equipment (PPE) was available for clinicians.

\subsection{Theme 2: Subjective Overload}

Subjective overload, a psychological term, relates to employees' perceptions of their situations, which, along with their coping mechanisms, decide the degree of stress they face at work (Hatton et al., 1999). For dentists, subjective overload is not restricted to their dental practice, but extends to other areas of their daily lives (Bandura, 2010). Self - efficacy is another important concept that refers to a person's confidence in performing at various levels, in response to real-time events, and to carry out the various behaviors required to achieve specific objectives (Benight \& Bandura, 2004). It has been highlighted that self-efficacy is important in a person's personal and professional growth, as well as in dealing with stressful situations and overcoming traumas (Shacham et al., 2020). Subjective overload has been investigated in 12 studies. It was ascertained by Shacham et al. (2020), that dental staff exhibiting high score for self - efficacy displayed less psychological distress, and dental staff with background illnesses were associated with higher levels of psychological distress. Moreover, Shacham et al. (2020) and Mekhemar et al. (2021), noted that dental staff in a committed relationship reported of lower psychological distress. Mijiritsky et al. (2020), concluded that positive association between subjective overload and psychological distress was different amongst countries, with Italian dentists showing more psychological distress in comparison to dentists from China, India, UK, and Israel. It was also found by Collin and Whitehead (2021), that psychological distress was attributed to feelings of betrayal, compounded by lost trust in leaders of the profession, and the lack of communication during the pandemic. Gasparro et al. (2020), Shetty et al. (2020), Tysiąc-Miśta and Dziedzic (2020), Majeed et al. (2021), Sarialioglu Gungor et al. (2021), Mahdee et al. (2020), and Mekhemar et al. (2021), found that female dentists seemed to be more concerned with COVID -19, and reported higher depressive symptoms than male dentists. In addition, Zhao et al. (2020), Sarialioglu Gungor et al. (2021), and Mahdee et al. (2020), noted that young staff reported of higher depressive symptoms than elderly staff. On the contrary, Sarapultseva, Zolotareva, Kritsky, Nasretdinova and Sarapultsev (2021), Shetty et al. (2020), and Majeed et al. (2021), noted that elderly staff exhibited greater levels of depression than young staff.

\subsection{Theme 3: Perceived Job Insecurity and Loss of Income}

Perceived job insecurity and loss of income was highlighted in 7 studies. It was established by Collin and Whitehead (2021), De Stefani, Bruno, Mutinelli and Gracco (2020), Mishra et al. (2020), Khanal and Singh (2020), Mahdee et al. (2020), that significant apprehension for the economic situation was felt by dentists. Gasparro et al. (2020), revealed that dentists with low fear of COVID -19 had weaker perceived job insecurity and depressive symptoms, compared to their colleagues who displayed higher fear to COVID - 19. Furthermore, Chakraborty et al. (2020) and Gasparro et al. (2020) found that young dentists with fewer years of work experience were associated with higher levels of depressive symptoms.

\section{Discussion}

This systematic review demonstrated an association between depressive symptoms among dental professionals 
and COVID - 19. It was also found that the extent of depressive symptoms was relatively consistent across the studies and could be attributed to 3 major factors, which include: fear of contagion, subjective - overload, and perceived job insecurity and loss of income.

Fear of contagion was seen to generate severe anxiety amongst dental professionals, particularly on being infected with COVID - 19, or passing the virus to family and friends. According to Rundall and Weiss (1994), fear of infectious disease is an ancient phenomenon, and health care workers might be expected to have accentuated concerns because their work would expose them to infection. According to the authors, Acquired Immunodeficiency Syndrome (AIDS) generates great anxiety, because it is prominent, fatal, epidemic disease with no cure or vaccine available. Currently, four COVID - 19 vaccines are listed in WHO's Emergency Use Listing (EUL), allowing these vaccines to be used by countries ("Status of COVID-19 Vaccines within WHO EUL/PQ evaluation process", 2021). However, WHO head Dr. Tedros Adhanom Ghebreyesus has stated that, while a vaccine is "essential for bringing the pandemic under control" it has to complement other pandemic fighting tools since "a vaccine on its own, will not end the pandemic" (Hart, 2020). Various causes, including the risk of being infected when treating an infected patient or infecting a family member, have been linked to psychological distress in healthcare workers during past outbreaks of related infectious diseases such as SARS (McAlonan et al., 2007; Ho, Kwong-Lo, Mak, \& Wong, 2005).

Subjective overload has also been responsible in contributing to depressive symptoms amongst dental professionals. This is because, during the COVID-19 pandemic, psychological distress is not limited to the virus itself, but may also be linked to social, cultural, and environmental factors, all of which could be added stressors (Mijiritsky et al., 2020). It was found by Shacham et al. (2020), that dental professionals with high self-efficacy exhibited lower psychological distress, and dental staff with background illnesses were associated with higher levels of psychological distress. According to the authors, this may be due to the fact that, chronically ill individuals might consider them more susceptible on getting COVID - 19. Furthermore, Shacham et al. (2020) and Mekhemar et al. (2021) found that, dental staff in a committed relationship reported of lower psychological distress. Similar findings were seen in the Second Xiangya Hospital, where Chinese medical workers, in order to boost their morale, were kept in touch with their families through video (Chen et al., 2020). A positive association was also established by Mijiritsky et al. (2020) between subjective overload and psychological distress, being different amongst countries, with Italian dentists showing more psychological distress in comparison to dentists from China, India, UK, and Israel. This difference in psychological distress could be due to difference in type of job stress amongst the dental personnel. Pal and Saksvik (2008) further elaborate, that difference in cultural and national backgrounds can affect the level of job stress. Another possible explanation for the high psychological distress faced in Italy, could be attributed to the Transactional Theory of Stress and Coping (TTSC) (Lazarus \& Folkman, 1984), which presents stress as the product of a transaction between a person (including multiple systems: cognitive, physiological, affective, psychological, neurological) and the complex environment in which he or she exists. Based on this, Armocida et al. (2020) suggested that, Italy faced a massive burden of COVID - 19 in the early stages of the pandemic, and Italian health service fragmentation and decentralization constrained timely interventions and effectiveness. Which was compounded, by the health systems' capacity and financing, not flexible enough to accommodate such an exceptional emergency. In addition, several dentists in Italy work in the private sector, and were badly affected due to COVID - 19. The combination of all these factors, could have resulted in Italian dentists experiencing high psychological distress, than their counterparts in other countries (Armocida et al., 2020). It was ascertained by Gasparro et al. (2020), Shetty et al. (2020); Tysiąc-Miśta and Dziedzic (2020), Majeed et al. (2021), Sarialioglu Gungor et al. (2021), Mahdee et al. (2020), Mekhemar et al. (2021), that COVID - 19 anxiety and depressive symptoms are more prevalent in females than in males. This finding is further supported in a study conducted by Wang et al. (2020), where it was observed that females underwent a greater psychological impact from the COVID - 19 outbreak than men, with higher levels of stress, anxiety, and depression. An explanation for this, might be linked with the fact that females generally show considerably greater risks than males in developing depressive disorders, anxiety, stress, as well as PTSD during adulthood (Altemus, Sarvaiya, \& Epperson, 2014). It was highlighted by Zhao et al. (2020), Sarialioglu Gungor et al. (2021), Mahdee et al. (2020), and Mekhemar et al. (2021), that young staff reported of higher depressive symptoms than elderly staff. According to Mahdee et al. (2020), older dentists reported less stress than younger dentists, as they may be more experienced in handling similar pandemic situations or emergencies, making them more confident and less prone to anxiety. Another possible explanation could be that, older people spend less time on social media (Xie, Watkins, Golbeck \& Huang, 2012), thus have less anxiety. This is because, high rates of news consumption in regards to COVID - 19 has been linked with elevated psychological distress (Gao et al., 2020). This was evident in the study conducted by Duruk et al. (2020), which emphasized that, as the dentists' 
awareness of COVID -19 grew, they experienced more psychological distress. Furthermore, Zhao et al. (2020), suggests that colleagues must support the younger staff who are much more vulnerable to developing anxiety disorders, and providing them with PPE to alleviate their concerns. On the contrary, Sarapultseva et al. (2021), Shetty et al. (2020), Majeed et al. (2021), noted that elderly staff exhibited greater levels of depression than young staff. Sarapultseva et al. (2021) noted that health care workers (HCW) aged $51-64$, exhibited highest depression and anxiety score. A possible explanation for this, according to the authors, is that this age group represents the pre - retirement age group in Russia, who are most vulnerable to the economic situation. Furthermore, Shetty et al. (2020) and Majeed et al. (2021), identified that older respondents were relatively anxious in all aspects. The authors attribute this to older respondents having medical comorbidities and other social issues. As seen in the study conducted by Shacham et al. (2020), whereby dental staff with background illnesses exhibited elevated psychological distress. Overall, nothing conclusively could be said about age and anxiety, as many other factors are involved. Collin and Whitehead (2021) found that psychological distress was also attributed to feelings of betrayal, compounded by lost trust in leaders of the profession, and the lack of communication during the pandemic. According to Ahmed, Zhao and Faraz (2020), when subordinates feel they are being cared for by their leaders using inclusive behavior, positive psychological conditions such as feelings of meaningfulness and safety is experienced.

Lastly, a pandemic often brings economic recession, and this is what happened during the first quarter of 2020 with COVID - 19, impacting every aspect of global economy (Consolo et al., 2020). According to Nicola et al. (2020), measures that have been enacted to stop the spread of COVID - 19, such as; large - scale quarantines, travel restrictions, and social - distancing measures, will result in a sharp decrease in consumer and business spending capacity until the end of 2020 and part of 2021. Such a scenario brings with it, a widespread sense of work insecurity (Spurk \& Straub, 2020), specifically the fear of losing one's job or the concern about keeping a job (De Witte \& Näswall, 2003). During the COVID - 19 outbreak, perceived job insecurity has been found to be a major stressor (Hamouche, 2020; Llosa, Menéndez-Espina, Agulló-Tomás, \& Rodríguez-Suárez, 2018), as it has a negative impact on the individual's financial capacity due to the high risk of financial loss (Zhou et al., 2020). It was highlighted by Collin and Whitehead (2021), De Stefani et al. (2020), Mishra et al. (2020), Khanal \& Singh (2020), Mahdee et al. (2020), that significant apprehension for the economic situation was felt by dentists. According to these authors, since the lockdown was imposed, dentists seemed to be struggling with financial hardships, and depression was associated with uncertainties surrounding job prospects and further financial burden due to investments in infection control procedures. According to Schwendicke, Krois and Gomez (2020), contraction of out - of pocket expenses of patients is likely even after the COVID - 19 associated measures are removed, because people will be faced with financial hardships resulting from the short - term immediate crisis, but also its mid - term economic continuation. Furthermore, the dental private sector is experiencing a financial crisis that is bound to worsen, due to the impending need of providing a better and safe working environment for the clinicians and patients. This will be reflected by an increase in business overheads and reduced profit margins (Consolo et al., 2020). It is expected for dental professionals to be apprehensive of their job and future prospects, which may lead to uncertainty about one's career and depressive symptoms. For instance, in a cross - sectional survey conducted by Nasseh and Vujicic (2020), 46\% of the dentists in the United States of America (USA), reported that they would file for bankruptcy or sell their dental practice, if delivery of elective dental procedures is restricted till August 2020 and beyond. Furthermore, U.S dental care spending has been projected to decline by up to 20 percent in 2021 (Nasseh \& Vujicic, 2020). According to Patel (2020), actions like these would mean high unemployment rates among dental practices, that recruit dental assistants, dental hygienist, dentists, dental assistants, and other auxiliary staff. As seen in the study conducted by Khanal and Singh (2020), where some dentists reported of losing their job or receiving no salary. Such outcomes may support the study conducted by Gasparro et al. (2020), which underlined that young dentists with fewer years of work experience had higher levels of depressive symptoms. Furthermore, Chakraborty et al. (2020) highlighted that significant level of depression was seen among young dental practitioners, who found it difficult to meet clinics and living expenses during the lockdown. Such economic uncertainty, together with the uncertainty about one's own job and the future in general, may result in serious psychopathological symptoms such as depression (Godinic, Obrenovic, \& Khudaykulov, 2020). In another comparable study conducted by Liang, Chen, Zheng, and Liu (2020), similar findings were observed when higher rates of depression were seen among young medical staff.

\section{Conclusion}

The 3 major factors found to be responsible for inducing fear, anxiety, and depression amongst the dental professionals during the COVID - 19 pandemic include: fear of contagion, subjective overload, perceived job insecurity and loss of income. The aim of this systematic review is to bring these causes to light, to underline the 
psychological trauma experienced by dental professionals during the COVID - 19 pandemic, and to aid in the development of mental health policies and strategies that benefit dental professionals. It is important for countries to enact measures that ensure positive mental wellbeing of dental staff, so that they are retained in the profession, and do not take any adverse action or decisions. Furthermore, if another pandemic or viral outbreak occur in the future, policies and strategies planned and implemented, will ensure dental professionals continue to deliver service without significant psychological distress.

\section{Competing Interests Statement}

The authors declare that there are no competing or potential conflicts of interest.

\section{References}

Ahmed, M., Jouhar, R., Ahmed, N., Adnan, S., Aftab, M., Zafar, M., \& Khurshid, Z. (2020). Fear and Practice Modifications among Dentists to Combat Novel Coronavirus Disease (COVID-19) Outbreak. International Journal of Environmental Research and Public Health, 17(8), 2821. https://doi.org/10.3390/ijerph17082821

Altemus, M., Sarvaiya, N., \& Epperson, C. (2014). Sex differences in anxiety and depression clinical perspectives. Frontiers in Neuroendocrinology, 35(3), 320-330. https://doi.org/10.1016/j.yfrne.2014.05.004

Ather, A., Patel, B., Ruparel, N., Diogenes, A., \& Hargreaves, K. (2020). Coronavirus Disease 19 (COVID-19): Implications for Clinical Dental Care. Journal of Endodontics, 46(5), 584-595. https://doi.org/10.1016/j.joen.2020.03.008

Armocida, B., Formenti, B., Ussai, S., Palestra, F., \& Missoni, E. (2020). The Italian health system and the COVID-19 challenge. The Lancet Public Health, 5(5), e253. https://doi.org/10.1016/s2468-2667(20)30074-8

Ahmed, F., Zhao, F., \& Faraz, N. (2020). How and When Does Inclusive Leadership Curb Psychological Distress During a Crisis? Evidence from the COVID-19 Outbreak. Frontiers in Psychology, 11. https://doi.org/10.3389/fpsyg.2020.01898

Bourassa, M., \& Baylard, J. (1994). Stress situations in dental practice. Journal (Canadian Dental Association), 60(1), 65-7. Retrieved from https://pubmed.ncbi.nlm.nih.gov/8293362/

Bandura, A. (2010). Self-Efficacy. In I. Weiner \& W. Craighead (Eds.), The Corsini Encyclopedia of Psychology (4th ed). Hoboken, New Jersey: John Wiley \& Sons.

Benight, C., \& Bandura, A. (2004). Social cognitive theory of posttraumatic recovery: the role of perceived $\begin{array}{lllll}\text { self-efficacy. Behaviour Research and } & \text { Therapy, }\end{array}$ https://doi.org/10.1016/j.brat.2003.08.008

Coronavirus Disease (COVID-19) - events as they happen. (2021). Retrieved 5 January 2021, from https://www.who.int/emergencies/diseases/novel-coronavirus-2019/events-as-they-happen

Chen, J. (2020). Pathogenicity and transmissibility of 2019-nCoV-A quick overview and comparison with other emerging viruses. Microbes and Infection, 22(2), 69-71. https://doi.org/10.1016/j.micinf.2020.01.004

Cooper, C., Watts, J., \& Kelly, M. (1987). Job satisfaction, mental health, and job stressors among general dental practitioners in the UK. British Dental Journal, 162(2), 77-81. https://doi.org/10.1038/sj.bdj.4806030

Cooper, C., \& Marshall, J. (1980). White collar and professional stress (pp. 1 - 257). Chichester: John Wiley \& Sons.

Chen, Y., Liu, Q., \& Guo, D. (2020). Emerging coronaviruses: Genome structure, replication, and pathogenesis. Journal of Medical Virology, 92(10), 2249-2249. https://doi.org/10.1002/jmv.26234

Consolo, U., Bellini, P., Bencivenni, D., Iani, C., \& Checchi, V. (2020). Epidemiological Aspects and Psychological Reactions to COVID-19 of Dental Practitioners in the Northern Italy Districts of Modena and Reggio Emilia. International Journal of Environmental Research and Public Health, 17(10), 3459. https://doi.org/10.3390/ijerph17103459

Chakraborty, T., Subbiah, G., \& Damade, Y. (2020). Psychological Distress during COVID-19 Lockdown among Dental Students and Practitioners in India: A Cross-Sectional Survey. European Journal of Dentistry, 14(S 01), S70-S78. https://doi.org/10.1055/s-0040-1719211

Collin, V., O'Selmo, E., \& Whitehead, P. (2021). Psychological distress and the perceived impact of the COVID-19 pandemic on UK dentists during a national lockdown. British Dental Journal, 1-8. https://doi.org/10.1038/s41415-020-2592-5 
Chen, Q., Liang, M., Li, Y., Guo, J., Fei, D., Wang, L., ... \& Zhang, Z (2020). Mental health care for medical staff in China during the COVID-19 outbreak. The Lancet Psychiatry, 7(4), e15-e16. https://doi.org/10.1016/s2215-0366(20)30078-x

De Witte, H., \& Näswall, K. (2003). 'Objective' vs 'Subjective' Job Insecurity: Consequences of Temporary Work for Job Satisfaction and Organizational Commitment in Four European Countries. Economic and Industrial Democracy, 24(2), 149-188. https://doi.org/10.1177/0143831x03024002002

Duruk, G., Gümüşboğa, Z. Ş., \& Çolak, C. (2020). Investigation of Turkish dentists' clinical attitudes and behaviors towards the COVID-19 pandemic: a survey study. Brazilian Oral Research, 34. https://doi.org/10.1590/1807-3107bor-2020.vol34.0054

De Stefani, A., Bruno, G., Mutinelli, S., \& Gracco, A. (2020). COVID-19 Outbreak Perception in Italian Dentists. International Journal of Environmental Research and Public Health, 17(11), 3867. https://doi.org/10.3390/ijerph17113867

Fazel, M., Hoagwood, K., Stephan, S., \& Ford, T. (2014). Mental health interventions in schools in high-income countries. The Lancet Psychiatry, 1(5), 377-387. https://doi.org/10.1016/s2215-0366(14)70312-8

Godinic, D., Obrenovic, B., \& Khudaykulov, A. (2020). Effects of Economic Uncertainty on Mental Health in the COVID-19 Pandemic Context: Social Identity Disturbance, Job Uncertainty and Psychological Well-Being Model. International Journal of Innovation and Economic Development, 6(1), 61-74. https://doi.org/10.18775/ijied.1849-7551-7020.2015.61.2005

Gao, J., Zheng, P., Jia, Y., Chen, H., Mao, Y.,Chen, S., ... \& Dai, J. (2020). Mental Health Problems and Social Media Exposure During COVID-19 Outbreak. SSRN Electronic Journal, 15(4), 1-10. https://doi.org/10.2139/ssrn.3541120

Gralinski, L., \& Menachery, V. (2020). Return of the Coronavirus: 2019-nCoV. Viruses, 12(2), 135. https://doi.org/10.3390/v12020135

Gasparro, R., Scandurra, C., Maldonato, N., Dolce, P., Bochicchio, V., Valletta, A., ... \& Marenzi, G. (2020). Perceived Job Insecurity and Depressive Symptoms among Italian Dentists: The Moderating Role of Fear of COVID-19. International Journal of Environmental Research and Public Health, 17(15), 5338. https://doi.org/10.3390/ijerph17155338

Huang, J., Han, M., Luo, T., Ren, A., \& Zhou, X. (2020). Mental health survey of medical staff in a tertiary infectious disease hospital for COVID-19. Chinese Journal of Industrial Hygiene and Occupational Diseases, 38(3), 192-195. https://doi.org/10.3760/cma.j.cn121094-20200219-00063

Hutton, B., Salanti, G., Caldwell, D., Chaimani, A., Schmid, C., Cameron, C., ... \& Moher, D (2015). The PRISMA Extension Statement for Reporting of Systematic Reviews Incorporating Network Meta-analyses of Health Care Interventions: Checklist and Explanations. Annals of Internal Medicine, 162(11), 777. https://doi.org/10.7326/m14-2385

Hatton, C., Rivers, M., Mason, H., Mason, L., Kiernan, C., Emerson, E., ... \& Reeves, D. (1999). Staff stressors and staff outcomes in services for adults with intellectual disabilities: the staff stressor questionnaire. Research in Developmental Disabilities, 20(4), 269-285. https://doi.org/10.1016/s0891-4222(99)00009-8

Hart, R. (2020). WHO Chief Warns Vaccine Won't End Covid-19 Pandemic as Moderna, Pfizer Announce Early $\begin{array}{lllll}\text { Successes. } & \text { Retrieved } & 25 & \text { January } & \text { 2021, }\end{array}$ https://www.forbes.com/sites/roberthart/2020/11/16/who-chief-warns-vaccine-wont-end-covid-19-pandemic -as-moderna-pfizer-announce-early-successes/?sh=36f4bec84d79.

Ho, S., Kwong-Lo, R., Mak, C., \& Wong, J. (2005). Fear of Severe Acute Respiratory Syndrome (SARS) Among Health Care Workers. Journal of Consulting and Clinical Psychology, 73(2), 344-349. https://doi.org/10.1037/0022-006x.73.2.344

Hamouche, S. (2020). COVID-19 and employees' mental health: stressors, moderators and agenda for organizational actions. Emerald Open Research, 2, 15. https://doi.org/ 10.35241/emeraldopenres.13550.1

Kang, L., Li, Y., Hu, S., Chen, M., Yang, C., Yang, B., ... \& Liu, K. (2020). The mental health of medical workers in Wuhan, China dealing with the 2019 novel coronavirus. The Lancet Psychiatry, 7(3), e14. https://doi.org/10.1016/s2215-0366(20)30047-x

Kamran, R., Saba, K., \& Azam, S. (2021). Impact of COVID-19 on Pakistani dentists: a nationwide cross sectional study. BMC Oral Health, 21(1), 1 - 7. https://doi.org/10.1186/s12903-021-01413-6 
Khanal, N., \& Singh, A. (2020). Knowledge, Attitude and Practice Regarding COVID-19 and its Impact on Dentistry: A Cross-sectional Survey among Nepalese Dentists. Kathmandu University Medical Journal, 18(2), 3-9. https://doi.org/10.3126/kumj.v18i2.32937

Kent, G. (1987). Stress amongst dentists. In R. Payne \& S. Firth-Cozens (Eds.), Stress and health professionals (1st ed., pp. 127-149). Wiley.

Llosa, J., Menéndez-Espina, S., Agulló-Tomás, E., \& Rodríguez-Suárez, J. (2018). Job insecurity and mental health: a meta-analytical review of the consequences of precarious work in clinical disorders. Annals of Psychology, 34(2), 211-223. https://doi.org/10.6018/analesps.34.2.281651

Lazarus, R., \& Folkman, S. (1984). Stress, appraisal, and coping (pp. 1 - 460). New York: Springer.

Liang, Y., Chen, M., Zheng, X., \& Liu, J. (2020). Screening for Chinese medical staff mental health by SDS and SAS during the outbreak of COVID-19. Journal of Psychosomatic Research, 133, 110102. https://doi.org/10.1016/j.jpsychores.2020.110102

Moore, R., \& Brødsgaard, I. (2001). Dentists' perceived stress and its relation to perceptions about anxious patients. Community Dentistry and Oral Epidemiology, 29(1), 73-80. https://doi.org/10.1034/j.1600-0528.2001.00011.x

Morawska, L., \& Milton, D. (2020). It Is Time to Address Airborne Transmission of Coronavirus Disease 2019 (COVID-19). Clinical Infectious Diseases, 71(9), 2311-2313. https://doi.org/10.1093/cid/ciaa939

Myers, H., \& Myers, L. (2004). It's difficult being a dentist': stress and health in the general dental practitioner. British Dental Journal, 197(2), 89-93. https://doi.org/10.1038/sj.bdj.4811476

Meng, L., Hua, F., \& Bian, Z. (2020). Coronavirus disease 2019 (COVID-19): emerging and future challenges for dental and oral medicine. Journal of Dental Research, 99(5), 481-487. https://doi.org/10.1177/0022034520914246

Morawska, L., \& Cao, J. (2020). Airborne transmission of SARS-CoV-2: The world should face the reality. Environment International, 139, 105730. https://doi.org/10.1016/j.envint.2020.105730

Mishra, S., Singh, S., Tiwari, V., Vanza, B., Khare, N., \& Bharadwaj, P. (2020). Assessment of level of perceived stress and sources of stress among dental professionals before and during the COVID-19 outbreak. Journal of International Society of Preventive \& Community Dentistry, 10(6), 794-802. https://doi.org/10.4103/jispcd.JISPCD_340_20

Majeed, M., Saleem, Z., Sarwar, H., Ramzan, Z., Iqbal, S., \& Naeem, M. (2021). The Psychology of Coronavirus Fear: Are Dentists of Pakistan Suffering from Corona-Phobia? Journal of The Pakistan Dental Association, 30(1), 1-6. https://doi.org/10.25301/jpda.301.1

Mijiritsky, E., Hamama-Raz, Y., Liu, F., Datarkar, A., Mangani, L., Caplan, J., ... \& Shacham, M. (2020). Subjective Overload and Psychological Distress among Dentists during COVID-19. International Journal of Environmental Research and Public Health, 17(14), 5074. https://doi.org/10.3390/ijerph17145074

Mahdee, A., Gul, S., Abdulkareem, A., \& Qasim, S. (2020). Anxiety, Practice Modification, and Economic Impact Among Iraqi Dentists During the COVID-19 Outbreak. Frontiers in Medicine, 7. https://doi.org/10.3389/fmed.2020.595028

Mekhemar, M., Attia, S., Dörfer, C., \& Conrad, J. (2021). The Psychological Impact of the COVID-19 Pandemic on Dentists in Germany. Journal of Clinical Medicine, 10(5),1008. https://doi.org/10.3390/jcm10051008

McAlonan, G., Lee, A., Cheung, V., Cheung, C., Tsang, K., Sham, P., ... \& Wong, J. (2007). Immediate and Sustained Psychological Impact of an Emerging Infectious Disease Outbreak on Health Care Workers. The Canadian Journal of Psychiatry, 52(4), 241-247. https://doi.org/10.1177/070674370705200406

Nasseh, K., \& Vujicic, M. (2020). Modeling the impact of COVID-19 on US dental spending-June 2020 update. Health Policy Institute Research Brief. Chicago (IL): American Dental Association.

Nicola, M., Alsafi, Z., Sohrabi, C., Kerwan, A., Al-Jabir, A., Iosifidis, C., ... \& Agha, R. (2020). The socio-economic implications of the coronavirus pandemic (COVID-19): A review. International journal of surgery (London, England), 78, 185-193. https://doi.org/10.1016/j.ijsu.2020.04.018

Ng, K., Poon, B., Kiat Puar, T., Shan Quah, J., Loh, W., Wong, Y., .. \& Raghuram, J. (2020). COVID-19 and the risk to health care workers: a case report. Annals of Internal Medicine, 172(11), 766-767. https://doi.org/10.7326/L20-0175 
Peng, X., Xu, X., Li, Y., Cheng, L., Zhou, X., \& Ren, B. (2020). Transmission routes of 2019-nCoV and controls in dental practice. International Journal of Oral Science, 12(1), 1-6. https://doi.org/10.1038/s41368-020-0075-9

Pal, S., \& Saksvik, P. (2008). Work-family conflict and psychosocial work environment stressors as predictors of job stress in a cross-cultural study. International Journal of Stress Management, 15(1), 22-42. https://doi.org/10.1037/1072-5245.15.1.22

Patel, N. (2020). Impact on Dental Economics and Dental Healthcare Utilization in COVID-19: An Exploratory Study. Journal of Advanced Oral Research, 11(2), 128-136. https://doi.org/10.1177/2320206820941365

Rundall, C., \& Weiss, D. (1994). Nurses' Fear of Contagion. Medical Decision Making, 14(1), 40-45. https://doi.org/10.1177/0272989x9401400105

Ren, Y., Rasubala, L., Malmstrom, H., \& Eliav, E. (2020). Dental Care and Oral Health under the Clouds of COVID-19. JDR Clinical \& Translational Research, 5(3), 202-210. https://doi.org/10.1177/2380084420924385

Schwendicke, F., Krois, J., \& Gomez, J. (2020). Impact of SARS-CoV2 (Covid-19) on dental practices: Economic analysis. Journal of Dentistry, 99, 103387. https://doi.org/10.1016/j.jdent.2020.103387

Sarialioglu Gungor, A., Donmez, N., \& Uslu, Y. (2021). Knowledge, stress levels, and clinical practice modifications of Turkish dentists due to COVID-19: a survey study. Brazilian Oral Research, 35. https://doi.org/10.1590/1807-3107bor-2021.vol35.0048

Spurk, D., \& Straub, C. (2020). Flexible employment relationships and careers in times of the COVID-19 pandemic. Journal of Vocational Behavior, 119, 103435. https://doi.org/10.1016/j.jvb.2020.103435.

Sarapultseva, M., Zolotareva, A., Kritsky, I., Nasretdinova, N., \& Sarapultsev, A. (2021). Psychological Distress and Post-Traumatic Symptomatology among Dental Healthcare Workers in Russia: Results of a Pilot Study. International Journal of Environmental Research and Public Health, 18(2), 708. https://doi.org/10.3390/ijerph18020708

Shacham, M., Hamama-Raz, Y., Kolerman, R., Mijiritsky, O., Ben-Ezra, M., \& Mijiritsky, E. (2020). COVID-19 Factors and Psychological Factors Associated with Elevated Psychological Distress among Dentists and Dental Hygienists in Israel. International Journal of Environmental Research and Public Health, 17(8), 2900. https://doi.org/10.3390/ijerph17082900

Stack, S. (2001). Occupation and Suicide. Social Science Quarterly, 82(2), 384-396. https://doi.org/10.1111/0038-4941.00030

Schardt, C., Adams, M., Owens, T., Keitz, S., \& Fontelo, P. (2007). Utilization of the PICO framework to improve searching PubMed for clinical questions. BMC Medical Informatics and Decision Making, 7(1), 1 6. doi: 10.1186/1472-6947-7-16

Status of COVID-19 Vaccines within WHO EUL/PQ evaluation process. (2021). Retrieved 1 April 2021, from https://extranet.who.int/pqweb/sites/default/files/documents/Status_COVID_VAX_01April2021.pdf

Shetty, A., Bhat, R., Shetty, P., Hegde, M., Nayak, U., \& D'souza, N. (2020). The psychological impact of the COVID-19 pandemic on dental healthcare professionals. Journal of International Oral Health, 12(8), 98. https://doi.org/10.4103/jioh.jioh_283_20

Tysiąc-Miśta, M., \& Dziedzic, A. (2020). The Attitudes and Professional Approaches of Dental Practitioners during the COVID-19 Outbreak in Poland: A Cross-Sectional Survey. International Journal of Environmental Research and Public Health, 17(13), 4703. https://doi.org/10.3390/ijerph17134703

Wang, C., Pan, R., Wan, X., Tan, Y., Xu, L., Ho, C., \& Ho, R. (2020). Immediate Psychological Responses and Associated Factors during the Initial Stage of the 2019 Coronavirus Disease (COVID-19) Epidemic among the General Population in China. International Journal of Environmental Research and Public Health, 17(5), 1729. https://doi.org/10.3390/ijerph17051729

Xie, B., Watkins, I., Golbeck, J., \& Huang, M. (2012). Understanding and Changing Older Adults' Perceptions and Learning of Social Media. Educational Gerontology, 38(4), 282-296. https://doi.org/10.1080/03601277.2010.544580

Zheng, J. (2020). SARS-CoV-2: An Emerging Coronavirus that Causes a Global Threat. International Journal of Biological Sciences, 16(10), 1678-1685. https://doi.org/10.7150/ijbs.45053 
Zhao, S., Cao, J., Sun, R., Zhang, L., \& Liu, B. (2020). Analysis of anxiety-related factors amongst frontline dental staff during the COVID-19 pandemic in Yichang, China. BMC Oral Health, 20(1), 1-7. https://doi.org/10.1186/s12903-020-01335-9

Zhou, X., Snoswell, C., Harding, L., Bambling, M., Edirippulige, S., Bai, X., \& Smith, A. (2020). The Role of Telehealth in Reducing the Mental Health Burden from COVID-19. Telemedicine and E-Health, 26(4), 377-379. https://doi.org/10.1089/tmj.2020.0068

\section{Copyrights}

Copyright for this article is retained by the author(s), with first publication rights granted to the journal.

This is an open-access article distributed under the terms and conditions of the Creative Commons Attribution license (http://creativecommons.org/licenses/by/4.0/). 